\title{
The Effect of "Kupas Rangkai" towards Reading Skill for Intellectual Disability Students of Grade IV in Special School
}

\author{
Janatu Rojiati, M. Shodiq AM \\ Universitas Negeri Malang, Indonesia \\ Email: rjanatu@ymail.com
}

\begin{abstract}
Rading has important position in learning proces, one of them student will be able to master various field studies. The subjects of this research have difficulties in basic reading. The purpose of this study was to know the effect of 'Kupas Rangkai' method towards reading skills for intellectual disability students of grade IV in Special School. The method was pre experiment with one group pretest-posttest design. Revenue in this research increased by 11 percen. So means there were differences of reading skill of intellectual disability students of grade IV before and after given treatment 'Kupas Rangkai' method. The suggestion for the teacher is make learning more creative and innovative.
\end{abstract}

Keywords: basic reading skill, kupas rangkai method, intellectual disability

Children with special need are children who experience physical disorder, intellectual disability and or social maladjusted that required special education services. One of them is intellectual disability. According to Efendi (2006) stated that "children with disabilities in the mental aspect are deviation children who experience the ability to think critically, logically in response to the surrounding world". There are two classifications of children with disability in the mental such as supernormal, able to learn fast, gifted and the genius and the subnormal like a intellectual disabilities.

Inflammation in the brain cause motor and mental disorder. This disorder causes children to be intellectual disability, because this disorder is closely related to the intellectual ability. If the child shows low intellectual from subnormality then the child will experience lags in the ability to process the information received. "The ability of intellectual disability to associate an idea with another idea is limited as in general children, as well as its ability to use information become make sense, take into account or predicted the possibility and evaluate a situation" (Abdurrachman \& Sudjadi, 1994).

The results of the observation on the students with intellectual disability at the fourth grade in learning process, they are less concentration, like to make rowdy, difficult in accepting abstract learning, difficult to think complicated, and teaching materials should be repeated. Students with intellectual disability can not memorized some alphabetical letter especially the b, $\mathrm{d}$, and $\mathrm{p}$. Students difficulty distinguishing letters. For example, the letter is $b$ spelled $d$ or $p$ and $d$ is spelled $b$. They have difficulty read the patterns of syllables. For example students are asked read word "baca", they say "daka". While, students correct spell namely "b-a-c-a", they say "d-a-k-a". Students have difficulty stringing pattern of words, for example, there is the word "babi", they say "dodi". The b spelled d, syllable "ba" spelled "do". Words that are spelled and read not sync. There is a word "palu" be read "beli. This method or manner of teachers who are interesting, media, and some aspects within the self students who make students are not able to read.

The early reading is a skill that must be taught on students. As skills, read needs special methods in order to students have basic reading skill, if students can control the basic reading skills, then students will easily pass through the next stages. Basic reading skill is more oriented towards the ability to read basic level, namely alphabet melek skill, that children can transform and recite the written symbols into meaningful sounds. At this stage it is possible the children could recite letter symbols are read without being followed by an understanding of the emblem sounds such symbols (Badan Pengembangan Profesi Guru, 2012).

One of the properties in the skills of reading is mechanical (mechanical skills). This skill has several aspects, as such; 1) The introduction of the shape of letters; 2) The introduction of linguistic elements (phoneme / grapheme, word, phrase, clause patterns, sentence, etc.); 3) Introduction of relations / correspondence patterns of spelling and sound (voice capability or the written material (to bank at print "); 4) Level speed reading child is slow in Tarigan, 2008). These three aspects are closely related to the existing capabilities in the concrete operational stage. In the stages of cognitive development of Jean Piaget, children 
aged 7-11/ 12 years of being in the concrete operational stage. "This period is marked by three new abilities and skills such as classify, organize and associate numbers" Efendi (2006) . In stages classify, the form vowel letter $\mathrm{a}$ is read, a consonant $\mathrm{b}$ is read b, etc. Stages establish, by introducing how to construct linguistic elements such as phoneme / grapheme, for example pronounced ba ba, etc. Stages associate, by way of introduction relations / correspondence patterns of spelling and sound (ability to vocalize written materials or (to a bank at a print "). For example, combining syllables patterned KV-KV being said, ba-bi-read ba-bi, etc. After a child passes these three stages, children can read though at a slow pace.

Based on research Asmiati (2013) entitled "Meningkatkan Kemampuan Membaca Permulaan pada Anak Tunagrahita Ringan melalui Metode Kupas Rangkai dengan Teknik Reposisi Bunyi”, was obtained that the students with MA (Mental Age) 6 (RA) the mean baseline level of phase 1 of $21.5 \%$, the mean level of the intervention phase $51.875 \%$, and the mean baseline level of phase 2 (A-2) of $49.5 \%$. While the students with MA 7 (SB) obtained a mean baseline level of phase 1 at $32.25 \%$, the mean level of the intervention phase $70.25 \%$ and the mean baseline level of phase 2 (A-2) amounted to $84.25 \%$. It can be concluded that the method of stripping the chain with sound repositioning techniques can improve the ability to read the beginning of the second student studied. This study used an experimental method of Single Subject Research (SSR) with the design model A-B-A. Students is that having two children with intellectual challenges MA 6 years (RA) and 7 years (SB). Children with MA 6 (RA) with intellectual disability children can recognize letters and the ability of children with MA 7 (SB) is a mild mental retardation of children with the ability to be able to spell. So the researchers used a Kupas Rangkai method on intelllectual disability students were grade IV to help trouble students to read. Based on the stages of cognitive, intellectual disability students are in the concrete operational stage.

"Kupas Rangkai is one method of reading starters (MMP) that describes the word, into syllables, into letters, into syllables and returned to the word" (Badan Pengembangan Pofesi Guru, 2012). The implementation is the teacher fold card word cards words into syllables, and then folded into the letters. Furthermore unfolded the letters into syllables and then unfolded the syllables into words. In conclusion break down words into syllables substituted by folding words into syllables, and so on.

The problem of this research is (1) how the reading skills of students with intellectual disability changing were before treatment?, (2) how retarded students' reading skills were performed after treatment?, and (3) is there a difference use Kupas Rangkai method to the reading skills of students with intellectual disability in the fourth grade Special School Idayu 2 Kabupaten Malang?. The purpose of this study was to determine the reading skills of a significant difference before and after treatment Kupas Rangkai method students with intellectual disability were grade IV in Special School Idayu 2 Kabupaten Malang. Benefits of the results of this research are: for teachers, this research can be used as consideration to improve the reading skills of students through the chain peel method.

\section{METHOD}

This research used experimental research. Sugiyono (2012) states that "experimental research method can be interpreted as the research methods used to find a specific treatment effect against the other in a state of control". This research was approach using pre-experimental. The design used in the form of one group pretest-posttest with one group of students. Implementation students are given a pretest to measure the ability of students before the beginning of the treatment given. After that, students are given the treatment using Kupas Rangkai method. The last stage, students are given a posttest that aims to determine the effect of reading skills. Before being given a pretest, researchers conducted observations and interviews with teachers to determine the characteristics of the students and the ability that has been owned by students. Samples taken in this study is 5 students. Instruments used in the form of interview, observation and test sheets. The test is test match and oral tests. The test results were obtained in the form of data used to analyze. Hypothesis testing using test Wicoxon. Data analysis using inferential statistics with SPSS 16.0 for Windows.

\section{FINDING AND DISCUSSION}

\section{Findings}

This research uses experimental research to determine the effect of Kupas Rangkai method to the reading skills of students with intellectual challenges were class IV. The study design using one group pretest posttest. At the initial stage the students are given a pretest, then given treatment with Kupas Rangkai method and the final stage students were given the posttest.

In the early stages of students experiencing difficulty in identifying letters $b$, d, p, for example identifying letter $b$, by looking for words that have the letter $b$. Once found, then circled, the student did circled words with the letter $\mathrm{d}$. In oral reading test, students puzzled to read words that read baba chest read, read read daca no words, no words read baba papa. 
Table 1. Results Comparison Values pretest and posttest

\begin{tabular}{ccccc}
\hline No & Name & $\begin{array}{c}\text { Pretest } \\
\text { Values }\end{array}$ & $\begin{array}{c}\text { Posttest } \\
\text { Values }\end{array}$ & $\begin{array}{c}\text { Changes } \\
\text { Signs }\end{array}$ \\
\hline 1. & Iy & 65 & 96 & + \\
2. & $\mathrm{Zi}$ & 75 & 84 & + \\
3. & $\mathrm{Et}$ & 57 & 82 & + \\
4. & $\mathrm{Dv}$ & 58 & 81 & + \\
5. & $\mathrm{Hk}$ & 56 & 77 & + \\
& Total & 311 & 420 & \\
& Average & 62 & 84 & \\
\hline
\end{tabular}

$\overline{\mathrm{N}}=5$

Table 2. Hypothesis Test Results

\begin{tabular}{ccccccc}
\hline No & $\mathrm{X}$ & $\mathrm{Y}$ & $(\mathrm{X}-\mathrm{Y})$ & $\begin{array}{c}\text { Rank } \\
(\mathrm{X}-\mathrm{Y})\end{array}$ & \multicolumn{2}{c}{ Signs } \\
\cline { 5 - 7 } & & & & 5 & - & -5 \\
\hline 1. & 65 & 96 & -31 & 5 sitive & Negative \\
2. & 75 & 84 & -9 & 1 & - & -1 \\
3. & 57 & 82 & -25 & 4 & - & -4 \\
4. & 58 & 81 & -23 & 3 & - & -3 \\
5. & 56 & 77 & -21 & 2 & - & -2 \\
\hline $\mathrm{N}=5$ & & & & &
\end{tabular}

Figure 1. Graph I Distribution of Value Comparison pretest and posttest

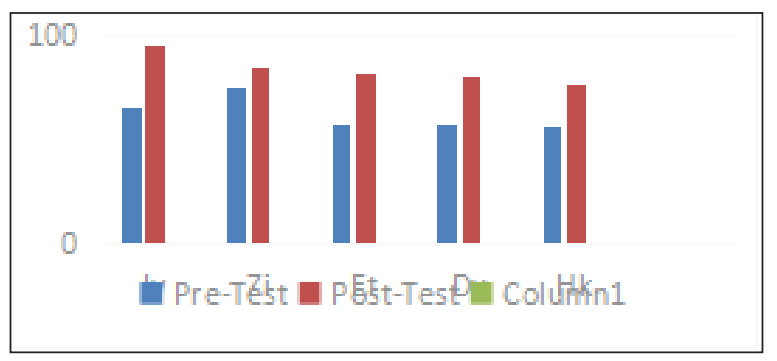

There was one of the students, who were able to identify the letters b, d, and p, but has not been able to read the word. For example the word papa read baba, be-li said read deli. Posttest at the end there is a difference before and after treatment Kupas Rangkai method. Students are able to distinguish the letters b, $\mathrm{d}$ and $\mathrm{p}$ by circling the word which has the first letter $\mathrm{b}, \mathrm{d}$ or $\mathrm{p}$ in accordance with the questions. Students are able to read even with spelling. Here are the values comparing pretest and posttest ".

In Table 1 shows the difference before and after treatment Kupas Rangkai method. The average value of 62 pre test and posttest average value of 84 so that the distance obtained at 22. Changes shown signs is + (plus) means an increase before and after treatment Kupas Rangkai method. After that table 1 are presented in graphical form.

The conclusion from these data is the average pretest score lower than the average posttest value. The difference shows the difference before and after Kupas Rangkai method to the reading skills of students with intellectual disability were class IV. Furthermore, data from the value pretest and posttest comparisons processed using SPSS 16.0 for Windows. The results are as follows (Tabel 3).

Based on table 3, the average yield of pretest and posttest have a range of 19. Range obtained from the maximum score at subtract the minimum score. The minimum score an average pretest score was 56 and the average value posttest maximum score is 77 . The average pretest score was 75 and the average value posttest is 96 . The total number of average pretest score was 311 and the average value posttest average was 420 . The mean of the average pretest score was 62 and the average value is 84 . Standard error posttest average pretest score was 3:56 and the average value posttest is 3.20. The standard deviation of the average value is 7.98 pretest and posttest average value is 7.17. Varian average pretest score was 63.7 and the average value was 51.5 posttest. Once the data is processed using the formula Wilcoxon, point to discover the results of hypothesis testing. Table 2 is values hypothesis test results of calculations using the Wilcoxon formula:

Based on the calculation of the total the absolute value is taken (the smallest) is $\mathrm{T}=0$ with $\alpha=0.05$ and $\mathrm{n}=5$, the price obtained table $\mathrm{T}=1$ means that $\mathrm{T} 0=0 \leq \mathrm{T}$ table $=1$ or $0 \leq 1$. In conclusion there are differences in the reading skills of fourth grade students with intellectual disability before and after treatment with Kupas Rangkai method. This study proved that there are significant Kupas Rangkai method to the reading skills of students with intellectual disability in the fourth grade Special School Idayu 2 Kabupaten Malang.

\section{Discussion}

At the first meeting before the students were given treatment with Kupas Rangkai method, students are given a pretest beforehand. Pretest aimed to determine students' initial conditions before being given treatment and to determine the extent of acquired reading skills of students in the fourth grade. The initial condition of fourth grade students with intellectual disability before given treatment by the method of Kupas Rangkai method as a method that helps students in basic reading is low. There are three items in question pretest. Pretest scores average value obtained was 62 . There were fourth votes in determining the outcome of an average score that distinguish letters, spelling words, reading words, and read simple words. Based on the average score of the Table 2. 
Tabel 3. Descriptive Statistics

\begin{tabular}{|c|c|c|c|c|c|c|c|c|c|c|}
\hline & & $\mathrm{N}$ & Range & Minimum & Maximum & Sum & \multicolumn{2}{|c|}{ Mean } & $\begin{array}{c}\text { Std. } \\
\text { Deviation }\end{array}$ & Variance \\
\hline & & Statistic & Statistic & Statistic & Statistic & Statistic & Statistic & $\begin{array}{l}\mathrm{S} \mathrm{t} \mathrm{d} . \\
\text { Error }\end{array}$ & Statistic & Statistic \\
\hline Pretest & & 5 & 19.00 & 56.00 & 75.00 & 311.00 & 62.2000 & 3.56931 & 7.98123 & 63.700 \\
\hline Posttest & & 5 & 19.00 & 77.00 & 96.00 & 420.00 & 84.0000 & 3.20936 & 7.17635 & 51.500 \\
\hline $\begin{array}{l}\text { Valid } \\
\text { (listwise) }\end{array}$ & $\mathrm{N}$ & 5 & & & & & & & & \\
\hline
\end{tabular}

students have not been able to distinguish the letters $b, d, p$, read words and simple sentences are not appropriate.

Problems in other activities influence the cognitive aspects such as attention, memory and language development is managed by the brain. Deficit experienced by children with intellectual disability include several key areas, namely (Mangunsong, 2009): a) Attention is necessary in the learning process. The intellectual disability child has learning difficulties due to focus on the wrong thing; b) Memory. Most of those who suffer from intellectual disability have difficulty in remembering information; and c) Language development. The intellectual disability child has developmental stages follow the same language with normal children, but their language development is usually too late to appear, slow progress and ends on the lower level of development.

Based on the above problems students have not been skilled at reading so students need a method in accordance with the conditions of students. Therefore, the researchers used a Kupas Rangkai method to help students skilled at reading starters.

After students perform pretest. Researchers treated through the kupas rangkai method to determine the effect of students with intellectual disability to reading skills. "Kupas Rangkai method is one method of reading starters (MMP) that describes the word, into syllables, into letters, into syllables and back into the word" (Badan Pengembangan Pofesi Guru, 2012). Its implementation provides the teacher then folded card word cards words into syllables, and then folded into the letters. Furthermore unfolded the letters into syllables and then unfolded the syllables into words. In conclusion break down words into syllables substituted by folding words into syllables, and so on.

The last stage did posttest. Problem tested when posttest is the same problem with the matter being tested pretest are 3 items that measure students' reading skills with the theme of family members. When the implementation of the posttest, students are given a card at random to read.

The reading skills of students with intellectual disability in the fourth grade Special School Idayu 2 Kabupaten Malang after getting treatment better results compared to before getting treatment with Kupas Rangkai method. The average scores of students posttest 82 . These results prove that there is a significant difference of reading skill students with intellectual disability at the grade IV before and after treatment Kupas Rangkai method.

In the concrete operational stage more emphasis on the function of memory (recalling) to learn something. However, children with intellectual disability have limited memory. Intelligence is below average, causing inaction thinking. Therefore, children with intellectual disability more emphasis on learning that repeated and customized learning (learning adaptation). One principle that individual learning is adaptive remedial learning programs that allow students to learn at the pace, opportunity, and learning styles of each (Iskandar, 2012). So the children with intellectual disability can develop, but slowly.

Based on the results of data analysis showed that there significant Kupas Rangkai method the reading skills of students with intellectual disability Special School Idayu 2. Early development of the student or pre test is presented in the table comparison of pretest and post test. The average value of 62 pretest and posttest average value of 84 . It can be concluded that the average posttest score higher than the average score of pretest values.

The reading skills of students with intellectual disability are influenced of the Kupas Rangkai method at Special School Idayu 2. Implementation of this method of word cards supported media. The first time the students read the word, then see the words into syllables, students read the syllable, folded syllables into letters, the students read the letter, open letters into syllables, students read the syllable and open syllables into words, students read word the loudly.

In the stages of cognitive development Jean Peaget, children aged 7-11/12 years of being in the Concrete Operational stage. "This period is characterized by three new abilities and skills that classify, organize and associate numbers or numbers" Efendi (2006) . One of the properties in the skills of reading is mechanical (mechanical skills). This skill has several aspects, namely; 1) The introduction of the shape of letters; 2) The introduction of linguistic elements (phoneme 
/ grapheme, word, phrase, clause patterns, sentence, etc.); 3) Introduction of relations / correspondence patterns of spelling and sound (voice capability or the written material (to bank at print "); 4) Speed reading level to slow in Tarigan (2008).

The introduction of the shape of the letter as classifying fonts. Provided letters $b$ and $d$, and then the students were asked to search for words beginning with the letters $b$ and $d$ and students classify words according to the letter prefix. The introduction of this letter using a card-shaped letters $b, d$ and $p$. Stages compiled by introducing phonemes, such weave patterns of phonemes for example there are letters $b$ and a. If organized into syllable $b a$ read $b a$. Stages associate spelling and sound patterns, such as spelling patterns $b, a, c, a$ read $b a c a$.

Changes experienced by students reading skills toward better in this study looks at the differences in the results of the average value of pre test and post test increased. The effect of the Kupas Rangkai method for students reading skills can be seen in using the Wilcoxon test hypotheses derived T $0=0$. While the price of $\mathrm{T}$ in the table with a real level $\alpha=0.05$ was obtained price table $T=1$. From the testing criteria have been established, then the price $\mathrm{T} 0=0 \leq \mathrm{T}$ tabel $=1$ or $0 \leq 1$. In conclusion there are differences in the reading skills of fourth grade students with intellectual disability before and after treatment with Kupas Rangkai method. It proves that there significant Kupas Rangkai method to the reading skills of students with intellectual disability in the fourth grade Special School Idayu 2 Kabupaten Malang.

\section{CONCLUSION AND SUGGESTION}

Based on the results obtained through the Wilcoxon test can be concluded that using the Kupas Rangkai method gives a good effect on the reading skills of fourth grade students with intellectual disability Special School Idayu 2 Kabupaten Malang. The results obtained through the scores obtained on the field by comparing pretest and posttest questions about the material identifying letters, read words and reading simple sentences. Score average value obtained pretest score of 62 and average value obtained posttest 84 . Results obtained percentage of 11 percent. This means that there is an increase in the average value before and after treatment Kupas Rangkai method. In field research students are given a pretest about getting results under KKM (Criterion Complete Minimal) but when given the treatment and posttest students do the problems get results above the KKM (Criterion Complete Minimal). From the results obtained, there significant Kupas Rangkai method to the reading skills of students with intellectual disability. This proves that there significant Kupas Rangkai method to the reading skills of students with intellectual disability in the fourth grade Special School Idayu 2 Kabupaten Malang.

Based on the conclusion of this study are for teachers, should be more creative and innovative in order to facilitate students learning to understand the teaching materials such as Kupas Rangkai method can be used as consideration in teaching reading difficulties students.

\section{REFERENCES}

Abdurrachman, M., \& Sudjadi, S. (1994). Pendidikan luar biasa umum. Jakarta: Depdikbud Direktorat Jendral Pendidikan Tinggi Proyek Pendidikan Tenaga Akademik.

Asmiati, N. (2013). Meningkatkan Kemampuan Membaca Permulaan pada Anak Tunagrahita Ringan Melalui Metode Kupas Rangkai dengan Teknik Reposisi Bunyi: Penelitian Subjek Tunggal Terhadap Anak Tunagrahita Ringan. (Doctoral dissertation, Universitas Pendidikan Indonesia).

Badan Pengembangan Profesi Pendidik. (2012). Pembelajaran Membaca \& Menulis di Kelas Rendah. Bahan Belajar Pendidikan dan Pelatihan Pasca-Uji Kompetensi Awal bagi Guru Kelas. Edisi 5. Jakarta: Badan Pengembangan Sumber Daya Manusia Pendidikan dan Kebudayaan dan Penjaminan Mutu Pendidikan (BPSDMPK dan PMP) Kementerian Pendidikan dan Kebudayaan.

Efendi, M. (2006). Pengantar psikopedagogik anak berkelainan.. Jakarta: Bumi Aksara.

Iskandar. (2012). Psikologi Pendidikan. Jakarta Selatan: Referensi.

Mangunsong, F. (2009). Psikologi dan Pendidikan Anak Berkebutuhan Khusus. Edisi 2009. Depok: Lembaga Pengembangan Sarana Pengukuran dan Pendidikan Psikologi (LPSP3).

Sugiyono. (2012). Metode Penelitian Pendidikan. Pendekatan Kuantitatif, Kualitatif, dan $R \& D$. Bandung:Alfabeta.

Tarigan, H. G. (2008). Membaca Sebagai Suatu Keterampilan Berbahasa. Bandung: Angkasa Bandung. 